\title{
Pengaruh Sistem Reward Dan Budaya Kerja Terhadap Kepuasan Kerja Dan Implikasinya Pada Kinerja Tenaga Kerja Indonesia Di Busan Korea Selatan
}

\author{
Aziz Muhammad \\ Mahasiswa Magister Manajemen Bisnis \\ Sekolah Pasca Sarjana Universitas Pendidikan Indonesia
}

\begin{abstract}
Abstrak
Sumber daya manusia merupakan pelaksana kegiatan produksi dalam mencapai tujuan perusahaan ditentukan oleh kualitas sumber daya manusia yang berperan penting dalam kegiatan operasional perusahaan. Berdasarkan pencapaian kinerja yang diukur dari hasil per pekerja tenaga kerja Indonesia di Korea Selatan belum optimal. Penelitian ini bertujuan untuk mengetahui gambaran sistem reward, budaya kerja, kepuasan kerja dan kinerja pada tenaga kerja Indonesia di Busan Korea Selatan.

Penelitian ini menggunakan metode descriptive explanatory survey. pengumpulan data dengan cara studi dokumentasi, dan penyebaran angket. Populasi penelitian ini adalah tenaga kerja Indonesia di Busan Korea Selatan yang berjumlah 2093 orang. Berdasarkan hasil perhitungan sampel dengan menggunakan rumus slovin diperoleh 336 orang yang terdistribusi secara proporsional. Untuk mengukur besarnya pengaruh sistem reward, budaya kerja dan kepuasan kerja terhadap kinerja, digunakan teknik analysis path (analisis jalur) dengan menggunakan software SPSS versi 23.

Hasil penelitian menunjukan bahwa sistem reward efektif, budaya kerja kuat, tingkat kepuasan kerja tinggi, tingkat kinerja tinggi. Sistem reward dan budaya kerja memiliki pengaruh positif terhadap kepuasan kerja. Pengaruh sistem reward, budaya kerja, dan kepuasan kerja memiliki pengaruh positif terhadap kinerja.
\end{abstract}

Kata Kunci: sistem reward, budaya kerja, kepuasan kerja, kinerja

\section{PENDAHULUAN}

Sumber daya manusia merupakan asset dalam sebuah perusahaan, karena perannya sebagai subyek pelaksana kebijakan dan kegiatan operasional perusahaan. Dalam kegiatan produksi sumber daya manusia merupakan input selain bahan baku dan modal. Sumber daya manusia merupakan sektor sentral dan penting dalam rangka pencapaian tujuan di suatu perusahaan, karena dengan adanya kemampuan para pekerja dan kualitas sumber daya manusia dapat menggerakan perusahaan dengan optimal.

Indonesia memiliki keunggulan dari jumlah penduduk dan sumber daya manusia yang besar. Walaupun kualitas sumber daya manusia tersebut harus terus ditingkatkan. Dalam suatu Negara, tenaga kerja ada yang dipekerjakan di dalam dan di luar Negeri.

Tabel 1.1

25 Negara Terbesar

Penempatan Tenaga Kerja Luar Negeri Indonesia

\begin{tabular}{|c|c|c|c|c|c|}
\hline \multicolumn{6}{|c|}{\begin{tabular}{l|l|l} 
Periode Tahun 2012 S.D 2015 \\
2012
\end{tabular}} \\
\hline No & NEGAR: & 2012 & 2013 & 2014 & 2015 \\
\hline 1 & Malaysiz & $(27 \%) 134,069$ & $(29 \%) 150,250$ & $(29 \%) 127,827$ & $(35 \%) 97.635$ \\
\hline 2 & Taiwenn & $(16 \%) 81,031$ & $(17 \%) 83,544$ & $(19 \%) 82,665$ & $(27 \%) 75,303$ \\
\hline 3 & Saudi Arabia & $(8.2 \%) 40.655$ & $(8.8 \%) 45,394$ & $(10 \%) 44,325$ & $(8.3 \%) 23,000$ \\
\hline 4 & Hong Kong & (9.1\%) 45,478 & $(8.1 \%) 41.769$ & (8.1\%) 35,050 & (5.5\%) 15,322 \\
\hline & Singapore & $(8.4 \%) 41,556$ & $(6.7 \%) 34,655$ & (7.3\%) 31,680 & (7.6\%) 20,895 \\
\hline 6 & Duberi & (7.2\%) 35,888 & $(8.6 \%) 44,505$ & (4.1\%) 17,962 & $(2.7 \%) 7.619$ \\
\hline & Qatar & (4.1\%) 20,380 & $(3.1 \%) 16,237$ & $(1.8 \%) 7,862$ & $(0.8 \%) 2,460$ \\
\hline & & & & & \\
\hline
\end{tabular}


Berdasarkan data di atas diketahui bahwa jumlah tenaga kerja Indonesia ke luar negeri mengalami kondisi fluktuatif. Jumlah tenaga kerja Indonesia ke Korea Selatan lebih sedikit dibanding dengan Malaysia, Taiwan, Saudi Arabia, Hong kong, Singapore, Dubai, Qatar. Peningkatan kuantitas tenaga kerja Indonesia harus diimbangi dengan kualitas kerja yang optimal.

Tenaga kerja Indonesia TKI memilih bekerja di Korea Selatan adalah karena negara tersebut merupakan salah satu negara maju diantara negaranegara penerima TKI lainnya. Proses pengiriman TKI ke Korea Selatan melibatkan berbagai instansi antar dua pihak sesuai yang tercantum dalam MoU. Dari Indonesia yang terlibat adalah Kementrian tenaga kerja dan transmigrasi serta Badan Nasional Penempatan dan Perlindungan Tenaga Kerja Indonesia BNP2TKI, sedangkan dari Korea Selatan yaitu Ministry of Employment and Labor MOEL dan Human Resources Development HRD Korea.

Berikut adalah data jumlah tenaga kerja Indonesia program $G$ to $G$ Korea Selatan.

Tabel 1.2

Penempatan Tenaga Kerja Indonesia Luar Negeri Program G To G Korea Selatan Tahun 2010 S.D 2015

\begin{tabular}{|c|c|c|}
\hline NO & TAHUN & JUMLAH TKI \\
\hline 1 & 2010 & $3964(10.16 \%)$ \\
\hline 2 & 2011 & $6325(16.21 \%)$ \\
\hline 3 & 2012 & $6410(16.42 \%)$ \\
\hline 4 & 2013 & $9441(24.19 \%)$ \\
\hline 5 & 2014 & $7382(18.92 \%)$ \\
\hline 6 & 2015 & $5505(14.11 \%)$ \\
\hline \multicolumn{2}{|c|}{ Total } & $39027(100.00 \%)$ \\
\hline
\end{tabular}

Sumber: Badan Nasional Penempatan dan Perlindungan Tenaga Kerja Indonesia BNP2TKI

Data di atas menunjukkan jumlah tenaga kerja Indonesia di Korea Selatan diketahui mengalami kenaikan dari tahun 2010-2013 dan terjadi penurunan pada tahun 2014-2015. Hal ini dikarenakan sedikitnya CTKI yang lulus seleksi dibandingkan tahun sebelumnya.

Berikut ini data penempatan tenaga kerja Indonesia di Korea Selatan berdasarkan sektor.
Tabel 1.3

Penempatan Tenaga Kerja Indonesia Luar Negeri Program G To G Korea Selatan Berdasarkan Sektor Tahun 2015

\begin{tabular}{|c|l|c|}
\hline NO & SEKTOR & JUMLAH TKI \\
\hline 1 & Manufacture & $4658(84.61 \%)$ \\
\hline 2 & Fishing & $839(15.24 \%)$ \\
\hline 3 & Construction & $5(0.09 \%)$ \\
\hline 4 & Agriculture & $3(0.05 \%)$ \\
\hline \multicolumn{2}{|c|}{ TOTAL } & $5505(100.00 \%)$ \\
\hline
\end{tabular}

Sumber: Badan Nasional Penempatan dan Perlindungan Tenaga Kerja Indonesia BNP2TKI

Berdasarkan data di atas mayoritas tenaga kerja Indonesia di Korea Selatan bekerja di sektor manufaktur. Diantara semua sektor, manufaktur menjadi sektor yang membuka banyak lowongan tiap tahun, seperti berdasarkan data terakhir pada tahun 2015 menunjukkan sektor manufaktur yang ditempati sebesar 84 persen.

Berikut ini kinerja tenaga kerja di Korea Selatan:

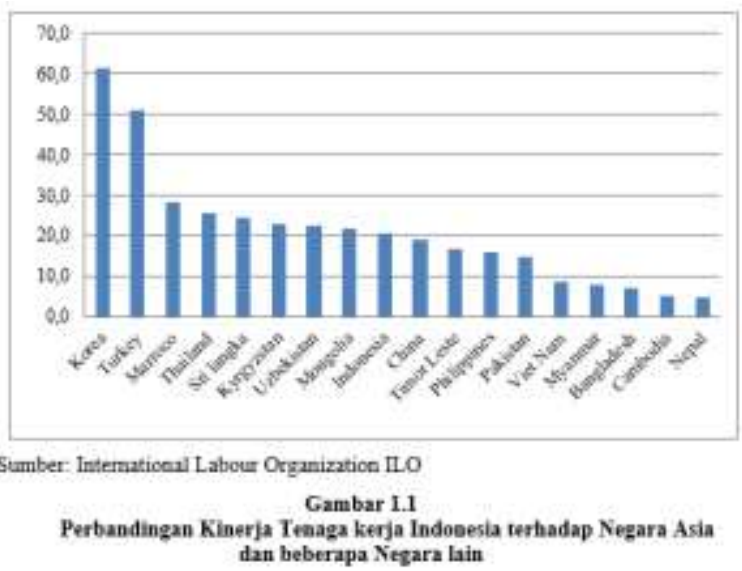

Berdasarkan data di atas kinerja yang diukur dari output per pekerja, Korea Selatan menempati posisi paling tinggi dan mengungguli rata-rata output per worker. Indonesia berada pada posisi pertengahan relatif lebih rendah dibandingkan Korea, Turki, Maroko, Thailand, Sri langka, Kirgistan, Uzbekistan, dan Mongolia.

Rendahnya kinerja akan mengambat pencapaian tujuan perusahaan, terutama dari segi pengembangan perusahaan ke arah yang lebih baik dalam mengadapi persaingan global.

Menurut Mangkunegara (2009:9) kinerja karyawan merupakan prestasi kerja atau hasil kerja (output) baik kualitas maupun kuantitas yang dicapai 
sumber daya manusia persatuan periode waktu dalam melaksanakan tugas kerjanya sesuai dengan tanggung jawab yang diberikan kepadanya.

Kinerja merupakan suatu masalah yang harus mendapat perhatian dari pihak perusahaan, karena peningkatan kinerja tidak akan terjadi dengan sendirinya, tetapi harus ada usaha dan peran serta dari pihak perusahaan maupun dari pihak tenaga kerja.

Berikut ini data jenis masalah yang dihadapi tenaga kerja Indonesia berdasarkan Negara penempatan.

\begin{tabular}{|c|c|c|c|c|c|c|c|c|c|c|}
\hline \multicolumn{11}{|c|}{$\begin{array}{l}\text { Tahel 14 } \\
\text { Senis masabah terbecar bendasarkan Negara penempatan }\end{array}$} \\
\hline No & $\begin{array}{c}\text { Jetis } \\
\text { Peinalution }\end{array}$ & seast & Marpea & spre & Kan & Teus & Singepoce & Kunzt & Quras & Tous \\
\hline 1 & 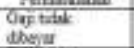 & $15 n$ & 176 & 119 & 196 & 79 & r & 104 & 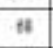 & 2000 \\
\hline 2 & Tringen & 1641 & 99 & 29 & $\$ \$$ & 30 & 23 & 3 & 34 & 284 \\
\hline 3 & 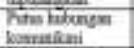 & 1573 & 296 & IIt & 96 & 47 & 71 & 94 & 34 & 215 \\
\hline 4 & Fenejast sat & $m$ & s) & $\pi$ & 67 & 70 & 19 & 4 & 26 & 1250 \\
\hline 3 & Besiunal dema & 462 & जIf & 24 & 16 & 6 & 17 & $z$ & $\delta$ & 979 \\
\hline 0 & 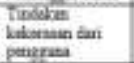 & 395 & $x$ & $x$ & $x$ & 12 & 16 & 6 & 24 & Not \\
\hline 7 & Fi wit & III & $\pi$ & i) & का & का & 19 & y & 25 & ग्रज \\
\hline 8 & PHK & 92 & 36 & 3 & 57 & 12 & 15 & LI & 35 & 386 \\
\hline 9 & 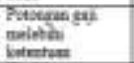 & III & is & 13 & $\pi$ & 31 & 10 & 7 & 4 & 280 \\
\hline 10 & Troderin & 1) & 2 & 5 & 1 & 2 & 1 & 4 & 11 & .76 \\
\hline 11 & Land dringitur & 156 & s) & 14 & 46 & 18 & 8 & 8 & 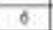 & 336 \\
\hline 12 & 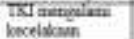 & 65 & $2 x$ & 3 & 28 & 20 & 12 & 10 & 13 & 199 \\
\hline & Iotal & QN2 & 1235 & 821 & 739 & $4 \pi$ & 306 & 392 & 207 & $150 \pi$ \\
\hline
\end{tabular}

Berdasarkan tabel di atas jumlah pengaduan dan banyaknya permasalahan yang terjadi pada tenaga kerja Indonesia (TKI) di Korea Selatan yaitu berhubungan dengan gaji, hubungan komunikasi dengan pimpinan atau rekan kerja, TKI memperoleh tindak kekerasan fisik dan verbal dari majikan sehingga para TKI kemudian melarikan diri dari majikan karena merasa tidak cocok dengan pekerjaannya, dan TKI mengalami kecelakaan kerja, baik dari human error maupun kesalahan pada mesin yang menyebabkan para TKI tersebut meninggal dunia. Masalah yang biasa diperoleh adalah saat TKI yang ingin berpindah perusahaan. Hal ini terjadi karena TKI merasa kurang puas dengan kondisi di lokasi kerja.

Masalah kepuasan kerja tersebut dikarenakan adanya tenaga kerja merasa belum puas atas kebijakan yang dibuat perusahaan. Menurut Robbins, (2003:139). Kepuasan kerja merupakan sikap umum seorang individu terhadap pekerjaannya, seorang dengan tingkat kepuasan kerja tinggi menunjukkan sikap yang positif terhadap pekerjaan itu, seorang yang tidak puas dengan pekerjaannya menunjukkan sikap negatif terhadap pekerjaan itu.

Salah satu cara perusahaan untuk dapat meningkatkan kepuasan kerja adalah dengan cara menetapkan sistem reward yang adil dan layak kepada tenaga kerja tersebut atas prestasi kerja yang dihasilkannya. Dengan cara memberikan kepada tenaga kerja berupa upah, promosi, pujian dan pengakuan untuk membantu menciptakan iklim yang menghasilkan pekerjaan yang lebih banyak tantangan dan memuaskan.

Tenaga kerja perlu mendapatkan perhatian agar mereka menjadi tenaga yang berkualitas dan mencapai kinerja yang tinggi. Terpenuhinya kesejahteraan tenaga kerja berpengaruh terhadap kepuasaan kerja dan menjadikan tenaga kerja yang produktif. Perusahaan mengharapkan umpan balik yang positif berupa tingkat kinerja yang tinggi sehingga keuntungan perusahaan bisa meningkat.

Dilihat dari faktor-faktor yang mempengaruhi kinerja, penulis melakukan penelitian dengan judul "Pengaruh Reward dan Budaya Kerja terhadap Kepuasan Kerja dan implikasinya pada Kinerja Tenaga Kerja Indonesia di Busan Korea Selatan".

\section{KERANGKA PENELITIAN \& HIPOTESIS}

Menurut Malayu Hasibuan (2007:118) kompensasi adalah semua pendapatan yang berbentuk uang, barang langsung atau tidak langsung yang diterima karyawan sebagai imbalan atas jasa yang diberikan kepada perusahaan. Kompensasi berbentuk uang, artinya kompensasi dibayar dengan sejumlah uang kertal kepada karyawan bersangkutan.

McShane \& Glinow (2010:416) budaya organisasi adalah nilai dan asumsi bersama dalam sebuah organisasi. Ini mendefinisikan apa yang penting dan tidak penting dalam perusahaan, dan mengarahkan setiap orang menuju cara yang benar dalam melakukan sesuatu.

Keith Davis yang dikutip oleh Mangkunegara (2009:117) mengemukakan bahwa Job satisfaction is the favorableness or unfavorableness with employees view their work. Wexley dan Yuki dikutip oleh Mangkunegara (2004:117) mendefinisikan bahwa 
kepuasan kerja adalah is the way an employee feels about his or her job. Artinya adalah cara pegawai merasakan dirinya atau pekerjaannya.

Menurut Sedarmayanti, (2010: 260). “Kinerja merupakan hasil kerja yang dapat dicapai oleh seseorang atau sekelompok orang dalam suatu organisasi, sesuai dengan wewenang dan tanggung jawab masing-masing, dalam rangka upaya mencapai tujuan organisasi bersangkutan secara legal, tidak melanggar hukum dan sesuai dengan moral maupun etika.

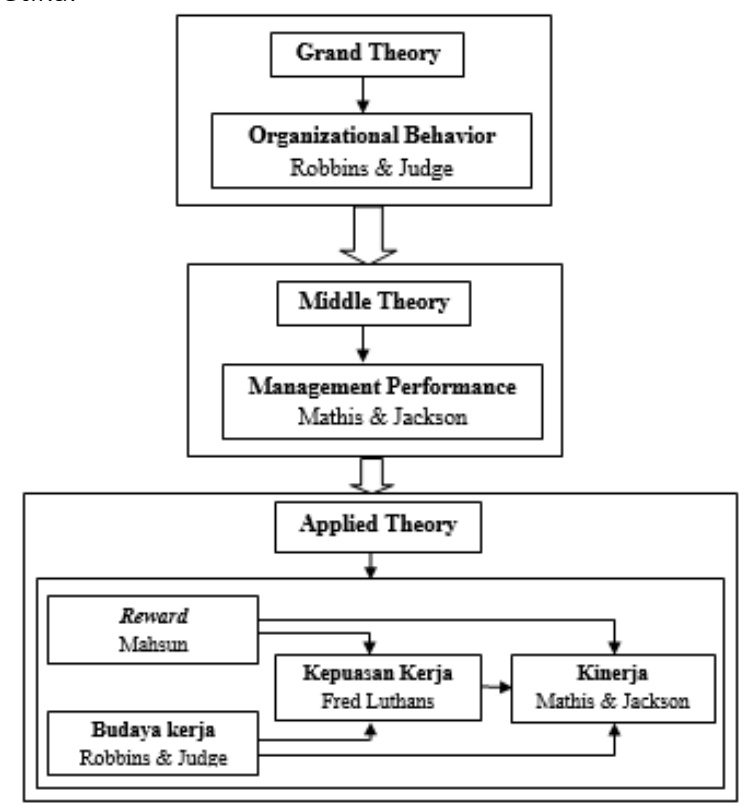

Gambar 2.1

Kerangka Pemikiran

Berdasarkan kerangka pemikiran yang sudah diuraikan sebelumnya, selanjutnya kerangka penelitian pengaruh sistem reward dan budaya kerja terhadap kepuasan kerja dan implikasinya terhadap kinerja pada tenaga kerja Indonesia di Korea Selatan dapat dilihat pada gambar di bawah ini:

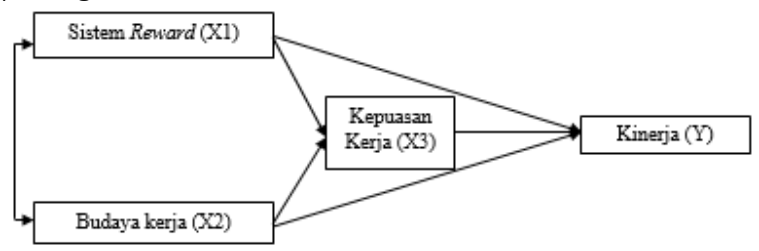

Gambar 2.2

Paradigma Penelitian

\section{Hipotesis Penelitian}

Berdasarkan pada kerangka pemikiran di atas, maka penulis merumuskan hipotesis sebagai berikut:

1. Gambaran sistem reward sudah efektif, gambaran budaya kerja kuat, gambaran kepuasaan kerja tinggi, dan gambaran kinerja tinggi.

2. Terdapat pengaruh positif dari efektivitas sistem reward dan kuat lemahnya budaya kerja secara simultan terhadap tingkat kepuasan kerja.

3. Terdapat pengaruh positif dari efektivitas sistem reward terhadap tingkat kepuasan kerja.

4. Terdapat pengaruh positif dari kuat lemahnya budaya kerja terhadap tingkat kepuasan kerja.

5. Terdapat pengaruh positif dari efektivitas sistem reward, kuat lemahnya budaya kerja dan kepuasan kerja secara simultan terhadap tingkat kinerja.

6. Terdapat pengaruh positif dari efektivitas sistem reward terhadap tingkat kinerja.

7. Terdapat pengaruh positif dari kuat lemahnya budaya kerja terhadap tingkat kinerja.

8. Terdapat pengaruh positif dari tingkat kepuasan kerja terhadap tingkat kinerja.

\section{METODE PENELITIAN}

Objek penelitian merupakan sasaran dalam melakukan penelitian. Objek penelitian ini adalah Tenaga Kerja Indonesia (TKI) di Busan Korea Selatan dengan variabel yang terdiri dari variabel bebas (independent) reward (X1), budaya kerja (X2), dan kepuasan kerja (X3) variabel terikat (dependent) adalah kinerja (Y).

Metode yang digunakan dalam penelitian ini adalah metode deskriptif explanatory survey yaitu metode survei yang bertujuan untuk menganalisis hubungan antar variabel.

Teknik pengumpulan data yang akan digunakan dalam penelitian ini adalah studi dokumentasi dan alat yang digunakan untuk pengumpulan data dalam penelitian ini adalah kuisioner (quisionnaires).

Populasi pada penelitian ini adalah Tenaga Kerja Indonesia (TKI) di Busan Korea Selatan yang berjumlah 2093 orang. Teknik sampling yang digunakan dalam 
teknik penarikan sampel berdasarkan peluang adalah Probability Sampling.

\section{HASIL DAN PEMBAHASAN}

\section{Deskripsi Sistem Reward}

Berdasarkan data yang diperoleh dari hasil skor kuesioner yang disebar kepada 336 responden tenaga kerja Indonesia di Busan Korea Selatan dengan empat dimensi yang dijadikan ukuran. Di bawah ini data rekapitulasi tanggapan responden terhadap variabel sistem reward.

Tabel 4.1

\begin{tabular}{l}
\multicolumn{4}{|c|}{ Rekapitulasi Tanggapan Responden terhadap Variabel Sistem Reward } \\
\begin{tabular}{|r|l|c|c|}
\hline No & \multicolumn{1}{|c|}{ Dimensi } & Perolahan Skor & Persentase \\
\hline 1 & Goal congruence (kesesuaian tujuan) & 4851 & $20 \%$ \\
\hline 2 & Equity (keadilan) & 5932 & $25 \%$ \\
\hline 3 & Equality (kemerataan) & 7154 & $30 \%$ \\
\hline 4 & Needs (kebutuhan) & 6116 & $25 \%$ \\
\hline & Jumlah & 24053 & $100 \%$ \\
\hline
\end{tabular}
\end{tabular}

Berdasarkan tabel di atas diketahui bahwa dimensi equality (kemerataan) memiliki skor paling tinggi yaitu 7154 (30\%), sementara yang paling rendah berada pada dimensi goal congruence (kesesuaian tujuan) dengan skor 4851 (20\%). Dengan empat dimensi yang digunakan untuk mengukur sistem reward pada tenaga kerja Indonesia di Busan Korea Selatan, tingkat equality (kemerataan) merupakan dimensi yang paling tinggi kontribusinya dalam pemberian sistem reward, karena persepsi karyawan dalam sistem pemberian reward yang diterapkan oleh perusahaan di Korea selatan telah didistribusikan secara merata bagi semua pihak yang telah berkontibusi untuk tercapainya kinerja yang optimal. Sedangkan dimensi goal congruence (kesesuaian tujuan) memiliki kontribusi paling rendah dalam pemberian sistem reward, karena setiap karyawan dalam perusahaan mempunyai tujuan individu yang sering tidak selaras dengan tujuan perusahaan. Dengan demikian, reward harus diciptakan sebagai jalan tengah agar tujuan perusahaan dapat dicapai.

\section{Deskripsi Budaya kerja}

Berdasarkan data yang diperoleh dari hasil skor kuesioner yang disebar kepada 336 responden tenaga kerja Indonesia di Busan Korea Selatan dengan tujuh dimensi yang dijadikan ukuran. Di bawah ini data rekapitulasi tanggapan responden terhadap variabel budaya kerja.

Tabel 4.2

Rekapitulasi Tanggapan Responden terhadap Variabel Budaya kerja

\begin{tabular}{|c|c|c|c|}
\hline No & Dimensi & Perolehan Skor & Persentase \\
\hline 1 & $\begin{array}{l}\text { Inovation and risk taking (Inovasi } \\
\text { dan Pengambilan Resiko) }\end{array}$ & 4820 & $17 \%$ \\
\hline 2 & $\begin{array}{l}\text { Attention to detail (Perhatian } \\
\text { terhadap detail) }\end{array}$ & 4601 & $17 \%$ \\
\hline 3 & $\begin{array}{l}\text { Outcome orientation (Orientasi } \\
\text { hasil) }\end{array}$ & 3634 & $13 \%$ \\
\hline 4 & People orientation (Orientasi orang) & 2398 & $9 \%$ \\
\hline 5 & Team orientation (Orientasi tim) & 4949 & $18 \%$ \\
\hline 6 & Aggressiveness (Keagresifan) & 3614 & $13 \%$ \\
\hline 7 & Stability (Stabilitas) & 3624 & $13 \%$ \\
\hline & Jumlah & 27640 & $100 \%$ \\
\hline
\end{tabular}

Berdasarkan tabel di atas diketahui bahwa dimensi team orientation (orientasi tim) memiliki skor paling tinggi yaitu 4949 (18\%), sementara yang paling rendah berada pada dimensi people orientation (orientasi orang) dengan skor 2398 (9\%). Dengan demikian tujuh dimensi yang digunakan untuk mengukur variabel budaya kerja pada tenaga kerja Indonesia di Busan Korea Selatan, team orientation (orientasi tim) paling tinggi kontribusinya dalam budaya kerja, karena kemampuan dan kemauan seorang karyawan dalam bekerja dengan tim sangat kuat, para anggota tim memiliki semangat kerjasama dalam satu tim perusahaan. Aktivitas kerja di perusahaan berdasar pada kerja tim daripada individual. Sedangkan dimensi people orientation (orientasi orang) memiliki kontribusi paling rendah, kurangnya perhatian dan dukungan dari perusahaan kepada pegawainya. Dalam pembuatan keputusan dan aturan dilakukan secara sepihak.

\section{Deskripsi Kepuasan Kerja}

Berdasarkan data yang diperoleh dari hasil skor kuesioner yang disebar kepada 336 responden tenaga kerja Indonesia di Busan Korea Selatan dengan lima dimensi yang dijadikan ukuran. Di bawah ini data rekapitulasi tanggapan responden terhadap variabel kepuasan kerja.

Tabel 4.3

Rekapitulasi Tanggapan Responden terhadap Variabel Kepuasan Kerja

\begin{tabular}{|c|l|c|c|}
\hline No & \multicolumn{1}{|c|}{ Dimensi } & Perolehan Skor & Persentase \\
\hline 1 & $\begin{array}{l}\text { The work it self (Pekerjaan } \\
\text { itu sendiri) }\end{array}$ & 4130 & $19 \%$ \\
\hline 2 & Pay (Gaji) & 5336 & $24 \%$ \\
\hline 3 & Promotion (Promosi) & 5208 & $23 \%$ \\
\hline 4 & Supervision (Pengawasan) & 3885 & $17 \%$ \\
\hline 5 & Co-workers (Rekan kerja) & 3653 & $16 \%$ \\
\hline & Jumlah & 22212 & $100 \%$ \\
\hline
\end{tabular}


Berdasarkan tabel di atas diketahui bahwa dimensi pay (gaji) memiliki skor paling tinggi yaitu 5233 (24\%), sementara yang paling rendah berada pada dimensi co-workers (rekan kerja) dengan skor 3653 (16\%). Dengan lima dimensi yang digunakan untuk mengukur variabel kepuasan kerja pada tenaga kerja Indonesia (TKI) di Busan Korea Selatan, pay (gaji) paling tinggi kontribusinya karena tujuan TKI bekerja ke Korea Selatan untuk mendapatkan gaji lebih tinggi dibandingkan dengan di Indonesia. Sedangkan dimensi co-workers (rekan kerja) memiliki kontribusi paling rendah, karena hubungan antara tenaga kerja asing dengan tenaga kerja lokal kurang bersahabat sehingga akan mempengaruhi semangat kerja. Perilaku atasan juga mempengaruhi kepuasan. Rekan kerja berhubungan dengan hubungan antara pegawai dengan atasannya dan dengan pegawai lain, baik yang sama maupun yang berbeda jenis pekerjaannya. Rekan kerja yang bersahabat, kerjasama rekan sekerja atau kelompok kerja adalah sumber kepuasan kerja bagi pekerja secara individual.

\section{Deskripsi Kinerja}

Berdasarkan data yang diperoleh dari hasil skor kuesioner yang disebar kepada 336 responden tenaga kerja Indonesia di Busan Korea Selatan dengan lima dimensi yang dijadikan ukuran. Di bawah ini data rekapitulasi tanggapan responden terhadap variabel kinerja.

\section{Tabel 4.4}

Rekapitulasi Tanggapan Responden terhadap Variabel Kinerja

\begin{tabular}{|c|l|c|c|}
\hline No & \multicolumn{1}{|c|}{ Dimensi } & $\begin{array}{c}\text { Perolehan } \\
\text { Skor }\end{array}$ & Persentase \\
\hline 1 & Quantity of output (kuantitas hasil) & 4139 & $23 \%$ \\
\hline 2 & Quality of output (kualitas hasil) & 3090 & $17 \%$ \\
\hline 3 & $\begin{array}{l}\text { Timeliness of output (waktu yang } \\
\text { dihasilkan) }\end{array}$ & 3506 & $19 \%$ \\
\hline 4 & Presence at work (kehadiran kerja) & 3699 & $21 \%$ \\
\hline 5 & Cooperativeness (kerjasama) & 3595 & $20 \%$ \\
\hline & Jumlah & 15220 & $100 \%$ \\
\hline
\end{tabular}

Berdasarkan tabel di atas diketahui bahwa dimensi quantity of output (kuantitas hasil) memiliki skor paling tinggi yaitu 4139 (23\%) sementara yang paling rendah berada pada dimensi quality of output (kualitas hasil) dengan skor 3090 (17\%). Dengan demikian lima dimensi yang digunakan untuk mengukur variabel kinerja pada tenaga kerja Indonesia di Busan Korea Selatan, quantity of output (kuantitas hasil) paling tinggi kontribusinya karena kuantitas hasil yang dicapai oleh seorang pegawai dalam melaksanakan tugasnya sesuai dengan tanggung jawab yang diberikan kepadanya. Sedangkan quality of output (kualitas hasil) memiliki kontribusi paling rendah pada kinerja, karena bekerja di perusahaan tersebut masing kurang dalam memberikan pelatihan kepada pegawainya, dan perusahaan lebih berorientasi pada kecepatan banyaknya hasil kerja sesuai dengan waktu yang ada dibandingkan dengan ketapatan dan ketelitian.

\section{Pengaruh efektivitas sistem reward, kuat lemahnya budaya kerja secara simultan terhadap tingkat kepuasan kerja}

Berdasarkan hasil pengolahan data dan uji statistik dapat diketahui besarnya kontribusi sistem reward dan budaya kerja berpengaruh positif secara simultan terhadap kepuasan kerja adalah 0,202 = 20,2\%. Hal ini menunjukkan bahwa masih terdapat faktor lain yang berpengaruh terhadap kepuasan kerja sebesar 79,8\%.

Meningkatnya kepuasan kerja juga disebabkan oleh sistem reward yang diberikan sudah semakin baik, sehingga tenaga kerja mendapat hak atas hasil kerjanya. Selain itu, semakin meningkatnya kepuasan kerja juga disebabkan oleh budaya kerja.

Perusahaan perlu memperhatikan kepuasan kerja dengan memberikan sistem reward yang adil agar karyawan dapat selalu mengeluarkan kemampuan terbaik dan meningkatkan kinerjanya dalam mencapai tujuan perusahaan.

\section{Pengaruh efektivitas sistem reward terhadap tingkat kepuasan kerja}

Berdasarkan hasil pengolahan data dan uji statistik dapat diketahui besarnya kontribusi reward yang secara langsung mempengaruhi kepuasan kerja adalah 0,340 = 34\%. Adanya pengaruh positif antara reward dengan kepuasan kerja.

Sistem reward yang efektif akan mampu memberikan kepuasan bagi karyawan dan ketika 
karyawan merasa terpuaskan dengan apa yang telah diperolehnya dari perusahaan, maka para karyawan akan menukarkannya dengan waktu, kemampuan, keahlian, dan usahanya untuk perusahaan kemudian akan bekerja secara maksimal sehingga hasil kerjanya akan optimal sesuai dengan standar kinerja yang ditetapkan.

Bagi perusahaan reward memiliki arti penting karena tujuan reward menurut Taylor dalam Manullang, (2008: 37), dapat mempertahankan karyawan yang ada agar tetap mau bekerja di perusahaan dan memberi lebih banyak dorongan agar para karyawan tetap berprestasi.

\section{Pengaruh kuat lemahnya budaya kerja terhadap tingkat kepuasan kerja}

Berdasarkan hasil pengolahan data dan uji statistik dapat diketahui besarnya kontribusi budaya kerja yang secara langsung mempengaruhi kepuasan kerja adalah 0,266 $=26,6 \%$. Terdapat pengaruh positif antara budaya perusahaan atau budaya kerja dengan kepuasan kerja. Sejalan dengan penelitian yang dilakukan Ketut (2010:289) menyatakan bahwa budaya kerja berpengaruh positif terhadap kepuasan kerja.

\section{Pengaruh efektivitas sistem reward, kuat lemahnya} budaya kerja, tingkat kepuasan kerja secara simultan terhadap tingkat kinerja

Berdasarkan hasil pengolahan data dan uji statistik dapat diketahui besarnya kontribusi sistem reward, budaya kerja dan kepuasan kerja berpengaruh secara simultan terhadap kinerja adalah 0,302 = $30,2 \%$. Sisanya sebesar 69,8\% dipengaruhi oleh faktorfaktor lain yang tidak dapat dijelaskan dalam penelitian ini. Sistem reward dan budaya kerja melalui kepuasan kerja terhadap kinerja karyawan memiliki pengaruh positif.

\section{Pengaruh efektivitas sistem reward terhadap tingkat kinerja}

Berdasarkan hasil pengolahan data dan uji statistik dapat diketahui besarnya kontribusi sistem reward yang secara langsung mempengaruhi kinerja adalah $0,428=42,8 \%$.
Adanya pengaruh positif dari sistem reward terhadap kinerja didukung oleh pendapat Nugroho (2006:5) bahwa: Reward adalah ganjaran, hadiah, penghargaan atau imbalan yang bertujuan agar seseorang menjadi lebih giat lagi usahanya untuk memperbaiki atau meningkatkan kinerja yang telah dicapai.

\section{Pengaruh kuat lemahnya budaya kerja terhadap tingkat kinerja \\ Berdasarkan hasil pengolahan data dan uji} statistik dapat diketahui besarnya kontribusi budaya kerja yang secara langsung mempengaruhi kinerja adalah 0,186 $=18,6 \%$. Terdapat pengaruh positif antara budaya kerja terhadap kinerja.

Budaya kerja harus dimiliki oleh suatu perusahaan agar pegawai memiliki nilai-nilai, norma, acuan, pedoman yang harus dilaksanakan. Budaya kerja juga sebagai pemersatu pegawai, peredam konflik dan motivator pegawai untuk melaksanakan tugas dengan baik, sehingga berpengaruh positif terhadap perilaku dan kinerja pegawai.

\section{Pengaruh tingkat kepuasan kerja terhadap tingkat kinerja \\ Berdasarkan hasil pengolahan data dan uji} statistik dapat diketahui besarnya kontribusi kepuasan kerja yang secara langsung mempengaruhi kinerja adalah $0,125=12,5 \%$. Terdapat hubungan positif kepuasan dan kinerja.

Dengan kepuasan kerja yang diperoleh, diharapkan kinerja yang tinggi dapat dicapai. Tanpa adanya kepuasan kerja, karyawan akan bekerja tidak seperti apa yang diharapkan oleh perusahaan, maka akibatnya kinerja karyawan menjadi rendah, sehingga tujuan perusahaan secara maksimal tidak akan tercapai.

\section{KESIMPULAN}

Gambaran efektivitas sistem reward pada tenaga kerja Indonesia di Busan Korea Selatan termasuk efektif. Gambaran efektivitas sistem reward yang memiliki persepsi tinggi pada dimensi equality 
(kemerataan), sementara skor yang paling rendah berada pada dimensi goal congruence (kesesuaian tujuan).

Budaya kerja pada tenaga kerja Indonesia di Busan Korea Selatan pada kategori kuat dengan menerapkan displin yang tinggi serta tingkat ketekunan yang sangat tinggi dalam bekerja karena dipengaruhi oleh budaya negara itu sendiri. Dimensi team orientation (orientasi tim) memiliki skor paling tinggi, sementara yang skor paling rendah berada pada dimensi people orientation (orientasi orang).

Tingkat kepuasan kerja pada tenaga kerja Indonesia di Busan Korea Selatan pada katagori tinggi. Dimensi pay (gaji) memiliki skor paling tinggi, sementara skor yang paling rendah berada pada dimensi co-workers (rekan kerja).

Tingkat kinerja pada tenaga kerja Indonesia di Busan Korea Selatan termasuk tinggi, dilihat dalam hal pengerjaan target produksi. Dimensi cooperativeness (kerjasama) memiliki skor paling tinggi, sementara yang paling rendah berada pada dimensi quality of output (kualitas hasil).

Terdapat pengaruh positif dan signifikan dari efektivitas sistem reward dan kuat lemahnya budaya kerja secara simultan terhadap tingkat kepuasan kerja pada tenaga kerja Indonesia di Busan Korea Selatan. Dengan dukungan efektivitas sistem reward dan kuat lemahnya budaya kerja dapat meningkatkan kepuasan kerja.

Terdapat pengaruh positif dan signifikan dari efektivitas sistem reward secara parsial terhadap tingkat kepuasan kerja pada tenaga kerja Indonesia di Busan Korea Selatan. Semakin efektif sistem reward maka akan semakin tinggi tingkat kepuasan kerja.

Terdapat pengaruh positif dan signifikan dari kuat lemahnya budaya kerja secara parsial terhadap tingkat kepuasan kerja pada tenaga kerja Indonesia di Busan Korea Selatan. Semakin kuat budaya kerja maka akan semakin tinggi tingkat kepuasan kerja.

Terdapat pengaruh positif dan signifikan dari efektivitas sistem reward, kuat lemahnya budaya kerja, tingkat kepuasan kepuasan kerja secara simultan terhadap tingkat kinerja pada tenaga kerja Indonesia di
Busan Korea Selatan. Tingkat pengaruh berkategori rendah, hal ini disebabkan oleh pengaruh faktor-faktor lain yang mempengaruhi kinerja selain reward, budaya kerja dan kepuasan kerja.

Terdapat pengaruh positif dan signifikan dari efektivitas sistem reward secara parsial terhadap tingkat kinerja. Semakin efektif sistem reward maka akan semakin tinggi tingkat kinerja.

Terdapat pengaruh positif dan signifikan dari kuat lemahnya budaya kerja secara parsial terhadap tingkat kinerja. Semakin kuat budaya kerja maka akan semakin tinggi tingkat kinerja.

Terdapat pengaruh positif dan signifikan dari tingkat kepuasan kerja secara parsial terhadap tingkat kinerja. Semakin tinggi tingkat kepuasan kerja maka akan semakin tinggi tingkat kinerja.

\section{REKOMENDASI}

Berdasarkan empat dimensi yang digunakan untuk mengukur sistem reward, goal congruence (kesesuaian tujuan) yang paling rendah. Untuk itu, inidividu diarahkan untuk mencapai tujuan perusahaan. Tujuan pribadi seseorang bisa selaras dan bisa juga tidak selaras dengan tujuan perusahaan. Ketidakselarasan tujuan mengakibatkan tujuan perusahaan atau tujuan individu tidak tercapai. Dengan demikian reward harus diciptakan sebagai jalan tengah agar tujuan perusahaan dapat dicapai.

Berdasarkan tujuh dimensi untuk mengukur budaya kerja, dimensi people orientation (orientasi orang) yang paling rendah. Usaha perusahaan untuk menciptakan kuatnya budaya kerja diharuskan. Dalam pembuatan keputusan memperhatikan data dan informasi dari pegawainya, dan penetepan aturan kebijaksanaan perusahaan yang standar.

Berdasarkan lima dimensi untuk mengukur kepuasan kerja, dimensi co-workers (rekan kerja) yang paling rendah. Karena dalam perusahaan terdapat tenaga kerja lokal dan tenaga kerja asing kurang bersahabat. Perusahaan harus menciptakan komunikasi dan hubungan yang baik antara rekan kerja. 
Berdasarkan lima dimensi untuk mengukur kinerja yang paling rendah berada pada dimensi quality of output (kualitas hasil). Untuk itu, perusahaan perlu meningkatkan kualitas tenaga kerja dengan cara memberikan pelatihan, memberikan reward dan bonus, dan mengaplikasikan atau menerapkan teknologi yang dapat membantu meningkatkan efisiensi dan efektifitas kerja.

\section{DAFTAR PUSTAKA}

Anwar Prabu Mangkunegara. 2009. Manajemen Sumber Daya Manusia Perusahaan. Bandung. Remaja Rosdakarya.

Robbins, Stephen P. 2003. Organizational Behavior, 10th ed., New Jersey. Prentice-Hall International, Inc.

Malayu S.P. Hasibuan 2007. Manajemen Sumber Daya Manusia, Edisi Revisi. Jakarta. Bumi Aksara.

McShane, Steven L dan Von Glinow, Mary A. 2010. Organizational Behaviour-Emerging Knowledge and Prectice For The Real World $5^{\text {th }}$ Edition. New York: McGraw-Hill

Sedarmayanti. 2010. Sumber Daya Manusia dan Produktivitas Kerja. Bandung. CV Mandar Maju.

Manullang, 2008, Dasar-Dasar Manajemen, Yogyakarta. Ghalia Indonesia.

Ketut, G. 2010. Pembuktian Budaya Organisasi pada Kepuasan Kerja. Jurnal Akutansi, Manajemen Bisnis dan Sektor Publik (JAMBSP). Vol, 6. No, 3. Juni 2010: 289.

Nugroho, Bambang. 2006. Reward dan Punishment. Bulletin cipta karya, departemen pekerjaan umum edisi no 6/IV/ juni 2006. Persada.

http://www.bnp2tki.go.id/26-November-2015 